\title{
ALLELOPATHIC EFFECTS OF CHROMOLAENA ODORATA (L.) KING \& ROBINSON ON SEED GERMINATION AND SEEDLINGS GROWTH OF PADDY AND BARNYARD GRASS
}

\author{
Meena Maiya Suwal*, Anjana Devkota* and H.D. Lekhak* \\ *Central Department of Botany, Tribhuvan University, Kirtipur, Kathmandu, Nepal.
}

\begin{abstract}
Viable seeds of paddy and barnyard grass in different concentrations of aqueous extracts ( 2, 4, 6, 8 and 10 \%) of leaf, stem and root of Chromolaena odorata were germinated at room temperatures. The leaf extract had strong inhibitory effect on seed germination as well as linear growth of paddy and barnyard grass. The order of inhibition was leaf $>$ stem $>$ root on both tested seeds. Allelopathic effect increased with increased concentration of the extracts.
\end{abstract}

Key Words: Allelopathy; Paddy; Barnyard grass; Aqueous extract; Root length; Shoot length.

\section{INTRODUCTION}

The allelochemicals may inhibit seed germination, shoot/root growth, nutrient uptake, or may attack a naturally occurring symbiotic relationship thereby destroying the plant's usable sources of a nutrient and effect allelopathic suppression of weeds to crops (Inderjit and Weston, 2000). A very important point concerning allelopathy is that its effect depends on a chemical compounds added to the environment .The most common feature studied is the seed germination response to allelochemicals. A seed germination assay, specifically radical elongation, allows for rapid analysis of various compounds suspected being allelochemicals.. Detrimental effects of allelochemicals on plants germination and growth have been reported (Bogatek et al., 2006).Leaf area can be reduced as a result of application of some synthetic allelochemicals (Patterson, 1981). Reduced leaf area could result in lower photosynthetic capacity for a plant and ultimately limit growth (Frederic and Camberato, 1995). Aqueous extract of the root of Helianthus tubarosus L. Ductuca sativa and Circium japonica all in the family of Asteraceae inhibit the growth of Amaranthus retroflexus, Cucumis sativa and Hordeum vulgare (Stachon and Zindel, 1980). Chromolaena odorata is a dominant, competitive shrub and the leaves contain a large amount of allelochemicals (Madrid, 1974) which retard the growth of crop plants. The fresh tissue extract prepared from Chromolaena odorota Helianthus annus and Tithonia diversifolia had an inhibitory effect on the germination and seedling growth of Vigna unguiculata (Ilory et al.2010).
These weeds are capable of posing a threat of phytotoxicity to agricultural crops.Considering the fact that these weeds grows in association with cultivated crops therefore the objective of this study was to determine the effect of aqueous extract of Chromolaena odorata on paddy together with associated weed, barnyard grass.

\section{MATERIALS AND METHODS}

The experiment was conducted under laboratory conditions in 2005. The vegetative parts of Chromolaena odorata were dried in shade. Ten gram dried and powdered plant parts was taken with $100 \mathrm{ml}$ of distilled water and kept for $24 \mathrm{~h}$ at room temperature and then filtered through double- layered muslin cloth. The filtrates served as the stock solution of $10 \%$ concentration. By subsequent dilution with distilled water leaf, root and stem extracts of $8 \%, 6 \%, 4 \%$ and $2 \%$ concentrations were prepared. Paddy and barnyard grass seeds were surface sterilized by dipping into $0.5 \%$ aqueous solution of sodium hypochlorite and rinsed several times with distilled water. Ten uniform seeds of paddy and barnyard grass were placed in separate petridishes lined with double layers of filter paper which was moistened with $10 \mathrm{ml}$ of aqueous extract. Control was maintained with distilled water. Each treatment was replicated thrice. Germination percentage, radicle and plumule lengths were measured at 7 days after sowing. The data were analyzed statistically using SPSS 10 version.

Author for Correspondence: Anjana Devkota, Central Department of Botany, Tribhuvan University, Kirtipur, Kathmandu, Nepal. E-mail devkotaa@gmail.com; mesuwal@yahoo.com. 
Table 1: Effect of aqueous extracts from leaf, stem and root on germination of paddy and barnyard grass.

\begin{tabular}{|c|c|c|c|}
\hline \multirow{3}{*}{ Parts used } & Extract Concentration (\%) & \multicolumn{2}{|c|}{ Seed Germination (\%) } \\
\cline { 2 - 4 } & & Paddy & $38 \pm 5.5$ \\
\hline \multirow{4}{*}{ Leaf } & 2 & $98 \pm 0.57$ & $30 \pm 5.19$ \\
\cline { 2 - 4 } & 4 & $78 \pm 4.04$ & $30 \pm 5.19$ \\
\cline { 2 - 4 } & 6 & $58 \pm 3.78$ & $18 \pm 2.88$ \\
\cline { 2 - 4 } & 8 & $28 \pm 2.30$ & $0 \pm 00$ \\
\hline \multirow{3}{*}{ Stem } & 10 & $14 \pm 2.30$ & $60 \pm 4.04$ \\
\cline { 2 - 4 } & 2 & $100 \pm 0.00$ & $38 \pm 5.03$ \\
\cline { 2 - 4 } & 4 & $98 \pm .057$ & $34 \pm 5.29$ \\
\cline { 2 - 4 } & 6 & $97 \pm 0.57$ & $24 \pm 5.77$ \\
\cline { 2 - 4 } & 8 & $94 \pm 4.657$ & $78 \pm 1.73$ \\
\cline { 2 - 4 } & 10 & $87 \pm 2.3$ & $48 \pm 5.5$ \\
\cline { 2 - 4 } & 2 & $100 \pm 00$ & $40 \pm 5.77$ \\
\cline { 2 - 4 } & 4 & $98 \pm 0.57$ & $34 \pm 4.04$ \\
\hline \multirow{3}{*}{ Root } & 6 & $98 \pm 57$ & $10 \pm 0.57$ \\
\hline
\end{tabular}

Note: \pm indicate the standard deviation from the mean value.

Table 2: Mean values of root and shoot length of paddy and barnyard grass germinated in different aqueous extracts. (Each value is the mean of 30 sample sizes; significance difference is shown by different letters at á $=0.05$ )

\begin{tabular}{|c|c|c|c|c|}
\hline \multicolumn{5}{|c|}{ Leaf extract } \\
\hline \multirow{2}{*}{ Treatment } & \multicolumn{2}{|c|}{ Paddy } & \multicolumn{2}{|c|}{ Barnyard grass } \\
\hline & Root Length (cm) & Shoot Length $(\mathrm{cm})$ & Root Length (cm) & Shoot Length $(\mathrm{cm})$ \\
\hline Control & $5.27 \mathrm{~d}$ & $4.22 \mathrm{~d}$ & $3.48 \mathrm{c}$ & $3.59 \mathrm{c}$ \\
\hline $2 \%$ & 2.61c & $2.92 c$ & $1.88 \mathrm{~b}$ & $2.14 \mathrm{~b}$ \\
\hline $4 \%$ & $0.86 \mathrm{~b}$ & $1.84 \mathrm{~b}$ & $0.55 a$ & $0.633 a$ \\
\hline $6 \%$ & $0.19 a$ & $1.31 \mathrm{~b}$ & $0.42 \mathrm{a}$ & $0.41 \mathrm{a}$ \\
\hline $8 \%$ & $0.1 \mathrm{a}$ & $0.54 a$ & $0.31 \mathrm{a}$ & $0.39 a$ \\
\hline $10 \%$ & $0.1 \mathrm{a}$ & $0.216 \mathrm{a}$ & $0.21 \mathrm{a}$ & $0.24 \mathrm{a}$ \\
\hline \multicolumn{5}{|c|}{ Stem extract } \\
\hline Control & $6.39 c$ & $3.94 \mathrm{~b}$ & $2.03 d$ & $5.15 c$ \\
\hline $2 \%$ & $6.48 c$ & $4.39 \mathrm{~b}$ & $0.93 c$ & $1.63 \mathrm{~b}$ \\
\hline $4 \%$ & $5.2 \mathrm{c}$ & $3.84 \mathrm{~b}$ & $0.67 \mathrm{bc}$ & $1.57 \mathrm{~b}$ \\
\hline $6 \%$ & $5.02 \mathrm{ab}$ & 3.49ab & $0.64 \mathrm{bc}$ & $1.31 \mathrm{~b}$ \\
\hline $8 \%$ & $4.81 \mathrm{ab}$ & $3.5 a b$ & $0.24 \mathrm{ab}$ & $0.65 \mathrm{ab}$ \\
\hline $10 \%$ & $3.78 a$ & $2.87 a$ & $0.001 \mathrm{a}$ & $0.001 \mathrm{a}$ \\
\hline \multicolumn{5}{|c|}{ Root extract } \\
\hline Control & $7.65 c$ & $4.16 \mathrm{~d}$ & $3.48 \mathrm{~d}$ & $3.59 \mathrm{~b}$ \\
\hline $2 \%$ & $1.62 \mathrm{~b}$ & $1.18 \mathrm{c}$ & $2.23 c$ & $3.1 \mathrm{~b}$ \\
\hline $4 \%$ & $0.71 \mathrm{ab}$ & $0.89 \mathrm{bc}$ & $0.71 \mathrm{~b}$ & $0.84 a$ \\
\hline $6 \%$ & 0.39ab & $0.38 \mathrm{bc}$ & $0.69 \mathrm{~b}$ & $0.48 a$ \\
\hline $8 \%$ & $0.25 a$ & $0.1 \mathrm{ab}$ & $0.52 \mathrm{ab}$ & $0.41 a$ \\
\hline $10 \%$ & $0.36 a$ & $0.21 a$ & $0.28 \mathrm{a}$ & $0.36 a$ \\
\hline
\end{tabular}

\section{RESULTS AND DISCUSSION}

The results obtained showed that different concentrations of aqueous extracts of different parts of Chromolaena odorata significantly reduced the germination of paddy and barnyard grass. The germination of barnyard grass was retarded more in comparison to the paddy among the aqueous extracts of leaf, root and stem. However, the aqueous extract of leaf had highest inhibitory effect on germination of paddy and barnyard grass in comparison to the aqueous extract of the stem and root. The inhibitory effect on germination increased with increase in concentration (Table 1). This was consistent with the finding of Indergit and Darkshimi (1994) who found that the water extracts from the roots of Pichea lanceolata in the family Asteraceae inhibited the germination of tomato and mustard. A similar study of Mulatu et al. (2006) reported that aqueous extract of Parthenium hysterophorus leaves and flower inhibited seed germination of lettuce.

The inhibitory effect on germination of barnyard grass was maximum in leaf extract in higher concentration (10\%) in which germination of barnyard grass was inhibited completely but 
the germination percentage in paddy was $14 \pm 2$.30. It may be due to large amount of the allelochemicals in leaf of Chromolaena odorata (Madrid, 1974). Inhibitory effects of leaf extracts of Ageratum conyzoids on seed germination and seedling growth of rice was also recorded by Malla (2003). Similar results have been obtained by Poudel (2004).

Radicle and plumule lengths of paddy were found to be affected by different aqueous extracts i.e. leaf, stem and root. Maximum reduction occurred in the seedlings of barnyardgrass in higher concentration of leaf extract (Table 2). But the shoot length of paddy was promoted from the aqueous extract of the different parts of plant in comparison to the barnyard grass. At higher concentration of Chromolaena odorata of different parts of aqueous extract the radicle growth was found to be more sensitive than plumule (Table 2). Similar differential effects on radicle and plumule growth were reported by Bhowmik and Doll (1982).

The present study revealed that aqueous extracts of Chromolaena odorata may contain water soluble allelochemicals which cause inhibitory effects on germination and seedlings growth of paddy and barnyard grass. The aqueous extract of leaf observed highly inhibitory effect on the germination of barnyard grass is due to the large amount of allelochemicals present in leaf of Chromolaena odorata.

\section{REFERENCES}

Bogatek, R.A., Gniazdowska, W., Zakzewkska, K.O. and Gawronski, S.W. 2006. Allelopahic effects of sunflower extracts on mustard seed germination and seedling growth. Plant. 50: 156-158.

Bhowmik, P. C. and Doll, J.D. 1982. Corn and Soya bean response to allelopathic effects of weed and crop residues. Agronomy Journal. 76: 383-388.
Frederic, J.R. and Camberato, J.J. 1995. Water and nitrogen effects of on winter wheat in the South Eastern coastal plain II. Physiol. Responses. Agronomy Journal. 17: 527-533.

Ilori, O.J., Otusanya, O.O., Adelusi, A.A. and Sanni, R.O. 2010. Allelopathic activities of some weeds in the asteraceae family. International Journal of Botany. 6: 161-163.

Indergit, K.M. and Darkshimi, M. 1994. Allelopathic effect of Pluchea lancaolala (Asteraceae) on characteristics of four soils and tomato and mustard growth. American Journal of Botany. 81: 799-804.

Inderjit, K. and Weston, L.A. 2000. Plant Allelochemicals Interference of Soil Chemical Ecology. Perspective in Plant Ecology, Evolution and Systematic. 4(1): 3-12.

Madrid, M.T. 1974. Evaluation of herbicides for the control of Chromolaena odorata (L.) R. M. King and H. Robinson. Phillippines Weed Science, Bulletin. 1: 25-29.

Mulatu, W., Gezahegn, B. and Befekadu, B. 2006. Allelopathic effect of Parthenium hysterophorus extract on seed germination and seedling growth lettuce. Tropical Science. 45: 159-162.

Malla, B. 2003. Allelopathic Potential of Ageratum sp M. Sc. Dissertation Central Department of Botany, Tribhuvan University, Kirtipur, Nepal.

Patterson, D.T. 1981. Effects of allelopathic chemical on growth and physiological responses of soyabean (Glycine max). Weed Science. 29: 53-59.

Poudel, P. 2004. Phytochemical Screening and Allelopathic Effect of Arimisia dubia Wall. Ex. Besser on seedling of Rice and Barnyardgrass. M. Sc. Dissertation, Central Department of Botany, Tribhuvan University, Kirtipur, Kathmandu, Nepal.

Stachon, W.J. and Zindel, R.L. 1980. Allelopathic activity of Canada thistle Cirsium arvense in Colorado. Weed Science. 28: 83-86. 